\title{
Non-Governmental Organizations Participation in Criminal Processes
}

\author{
AkbarVarvaii $^{1}$, HematMohamadi ${ }^{2}$ \&Ayyoub Nourian ${ }^{3}$ \\ ${ }^{1}$ Department of Law, Amin Police University, Iran \\ ${ }^{2}$ Department of Law, Kermanshah Branch, Islamic Azad University, Kermanshah, Iran \\ ${ }^{3}$ Department of Law, Central Tehran Branch, Islamic Azad University, Tehran, Iran \\ Correspondence: AkbarVarvaii, Department of Law, Amin Police University, Iran. E-mail: \\ ar.ahmadie@gmail.com
}

Received: June 8, 2016 Accepted: July 9, 2016 Online Published: October 30, 2016

doi:10.5539/jpl.v9n9p110 URL: http://dx.doi.org/10.5539/jpl.v9n9p110

\begin{abstract}
Despite their long-time physical presence in our country (Iran), non-governmental organizations (NGOs) have not been taken seriously by the government and public institutions, and play no effective role in criminal proceedings. An innovative by 2013 criminal procedure code is to realize doctrine of participatory criminal policy through NGOs participation in criminal proceedings, which has been provided for by legislator in Article 66 of mentioned code which was amended suddenly within a few days prior to being approved to come into effect on the basis of an interesting decision and which degraded NGOs' right to litigate into the limit of that of indictors and viewers at proceedings.

During proceedings, NGOs play the role of indictors and viewers, regardless of the lack of legal, cultural and social grounds necessary for them to take an active part in criminal proceedings in our country; and, in effect, they face such limitations and ambiguities as criteria of the recognition of their qualifications to do so (Article 66, provision 3). In addition, it is not clear how to develop NGOs' participation in criminal proceedings and how to monitor their activities. Present study is intended to examine grounds of and barriers to NGO's activity in criminal proceedings and to address vital roles they can play in the crime prevention and their involvement with criminal proceedings.
\end{abstract}

Keywords: participatory criminal policy, indictors, public claims, criminal proceedings

\section{Introduction}

Increased growth of criminal phenomenon in modern days, along with the advent of new, diverse forms of misdemeanor and delinquency have entailed failure of formal criminal justice system in adopting criminal penalties to prevent crimes from being committed and to counter delinquency as well as to correct criminals behaviorally. As a result, this encouraged domestic criminal policy-makers to increase and strengthen programs of criminal policy based on more active participation of civil society in criminal processes as much as possible.

In general, two participation models, hence two traditional and civil organizations, can be distinguished. The first one is a traditional participatory model based on traditions, practices, habits and religion, which is in existence among society members institutionally and spontaneously, being a response to the needs caused by historical changes and a product of many years of participation transferred from one generation to another. In this model, government plays no guiding and organizing roles, with people being responsible for doing tasks. The second model relates to NGOs' participation. NGOs are grass root populations, groups and institutions spontaneously emerged from the society heart, performing non-profit and voluntary activities to solve social problems and to serve general public, and considering their own highest advantage as being independent of government.

In line with new thoughts of participatory criminal policy, 2013 criminal procedure code bill accepted NGOs' involvement through indiction and participation in proceedings on some conditions in order to support vulnerable victims and citizenship rights, and to protect such public rights and interests as environment, natural resources, cultural heritage and public health, turning their merely indicting status into that of an active follower. But after the amendment in 15/06/2015, NGOs' rights to raise evidence and to object to judicial verdicts, provided for in the bill, were omitted from text of the Article so that the new achievement of a controversial act of criminal procedure code has been forgotten. 
To expand NGOs' participation in criminal proceedings depends on the provided activity grounds and on supervision and evaluation of such activities in order to eliminate barriers and flaws caused by NGOs' involvement.

\section{Non-Governmental Organizations: Definition, Background and Objectives}

NGOs are grass root populations, groups and institutions spontaneously emerged from the society heart, which do non-profit and voluntary activities in order to remove social problems and to serve general public, and which consider their own most significant advantage as being independent of government. Considered among newly founded civil organizations, NGOs are established and operated by motivated citizens' voluntary collaboration to do group/ collective activities in the form of a coherent structure and organization with the aim of contributing to social development and welfare and to society members' empowerment without any dependence on the government.

NGOs have various objectives and, typically, move toward advancement of political or social goals of society members; for example, to improve environmental conditions, to encourage people and groups to observe Human Rights, to raise the welfare level of deprived people, and to offer collectively joint programs. Such organizations are numerous in number and their objectives include a broad spectrum of political and philosophical situations. In Iran, democratic formations have a historically deep-rooted background. Since human social life developed in rural and, then, in urban areas, in fact, the need for contribution and participation was felt; next, the rich began to help the poor, so a sort of helping was shaped and institutionalized individually and collectively.

The first Iranian environmental NGO was Ashkzar rural group, Yazd, which started its activities aiming at stabilizing dune and non-desertifying in the early 1970. With significant growth of 22, 156 and 550 environmental NGOs by 1996, 1999 and 2003, respectively, this trend reflects public endeavor to take part in this domain activities (Golmohammadi, Yosefi, 2009: 11).

Participatory approach has been of interest in ancient Iranian culture either in pre- or in post- Islamic periods. International instruments and treaties, especially those negotiated at $6^{\text {th }}, 7^{\text {th }}, 9^{\text {th }} \mathrm{UN}$ conferences, on crimes prevention and criminals correction have placed emphasis on citizens' and civil institutions' participating in activities regarding crime prevention and penalty execution.

Exploiting comparative studies performed since 1960s, criminal policies of developed countries have seen development of reforms based on community participation in various areas of criminal justice, including society-centered prevention, community criminal's correction and rehabilitation, and observance of prosecution proportionality principle in direction of society - and justice - centered development. In Iran, participatory approach is originally tracked in guild houses and arbitration councils prior to Islamic Revolution and in drugs combat headquarter programs for preventing drugs use after Islamic Revolution. In addition, development of a nationally society-centered crime prevention program; public participation in criminal processes; establishment of conflict settlement councils; intercession during criminally preliminary investigations; NGOs' activities in protecting vulnerable groups such as street children and women victimized by home violence; establishment of associations supporting prisoners and their families, blood-money headquarters, organs providing free consultation; and legal services provided to the poor individuals and prisoners can be mentioned (Jamshidi, 2011: 28).

Although NGOs have been active for many years in our country, they have not been taken seriously by the government and public institutions, and play no effective roles in this sector. They are also known as "associations", "populations", "groups", "houses", etc.; and it can be said that their new form was established simultaneously with approval of statute of NGOs establishment and activity in 2005, with reference to constitutional principle 138. Such formations are established by emphasizing on being volunteer, non-profit and non-political, and funded by public donations, membership fees, and grants from international non-governmental, and sometimes governmental, organizations. Perhaps one reason why NGOs have no strong presence is that they were not supported by other governmental agencies and not invited to have a part in relation to socially serious issues in the past.

NGOs' activities are divided into 2 categories: activities performed to react to violation of a right, being called reactive activities; and those performed with a predetermined program but without a violation ground. In fact, the second category of activities starts on the basis of necessity of a right existence, which is called hyperactive. Such activities are preventive and result in mechanisms helping to realize individuals' rights multidimensionally (Nouri Neshat, 20006: 68). Obviously, under Article 66 of criminal procedure code, NGOs are allowed to take part in related proceedings in response to crimes committed in mentioned areas. 


\section{Participatory Criminal Policy}

Historically, term 'criminal policy' was used first by Feuerbach, a German Juristic scholar, in book Criminal Law published in 1803. Criminal policy is an academic field trying to formulate and create (criminally) repressive and preventive doctrine which can be imposed on criminals and delinquents in accordance with philosophical and scientific data and findings, including those of criminology, and with the given historical circumstances. This definition given by Von Liszt (Who co-founded the International Criminal Law Association, Germany, 1889) attracted attention of Marc Ancell (French Judge) somewhat differently in 1954. He believed that criminal policy is both a science and a technique, subject - matter of which is to provide the best practice to codify case rules and regulations in the light of findings of criminology (NajafiAbrandabadi\&Hashembeigi, 2011: 98).

Term 'criminal policy' attributed generally to the book by Feuerbach, German Professor, in 1803, have long remained interchangeable with theoretical and practical aspects of criminal systems. According to Feuerbach, criminal policy includes a set of repressive practices anticipated and adopted by governments to react to crimes. Today, however, criminal policy is separated from criminal law, criminology and criminal sociology, taking an independent concept. Having established "Criminal Policy Archives" publication in 1975, Marc Ancell placed emphasis on criminal law in his first attempt necessitating not limiting and summarizing criminal policy. And trying to highlight its hybrid feature, namely "observation and study knowledge", and "systematic technique or strategy of reaction against crimes", he proposed a definition of criminal policy as "some organized, studied reaction of society to criminal, deviant or antisocial acts and activities" (Mireille Delmas - Marty, 2014: 69). This term has prevailed largely in countries with written law, with no place in English - speaking countries. In this regard, Marc Ancell says, "American criminologists and sociologists - at least in the U.S. - had missed the point even in using term 'criminal policy' (Ancell, 1975: 21).

Term 'criminal policy' with a bit more than two centuries background full of ups and downs is regarded as an independent academic field in criminology today. Within its course of emergence, concept of criminal policy has seen significant changes so that it turned from a limited concept into an extended one (Hosseini, 2004: 23). Experts in the field of criminal policy argue that 3 types of legislative, judicial and participatory criminal policies are observed in the stage of accepting a criminal policy, which are, in fact, its manifestation in practical phases and in any particular country (lazorge, 2003: 93). In Iran, DrMatinDaftari was the first to use this term interchangeably with term 'Penal policy' (Quoted from Abrandabadi; Jamshidi, 2011: 19).

Participatory criminal policy is considered the newest and most important criminal policy tendency recently emerged in West for political, social, economic and criminological reasons and factors, in particular, for crisis of inefficiency and inability of criminal justice systems to use traditional tools of criminal law in order to combat criminal phenomenon, so it is a few decades old (Rostami, 2007: 140).

In general, participatory criminal policy purpose is to study position given to civil society within criminal policy of a certain country by giving roles to criminals, victims, and society at large. Responses given by civil society through these 3-fold elements are termed social responses (Delmas-Marty, 2002: 83; lazorge, 2003: 61).

In addition to participation of state actors, participation by mass media, associations and citizens or, in general, by civil society is a necessity inevitably to reach consensus on a criminal policy, not to diminish the government role, but for the reason that civil society is an important entity as major criminal policy actors, so they must naturally take part in affairs actively (lazorge, 2003: 139). To engage civil society, especially people, in this process implies, regardless of reflecting public competency in this area, that crime prevention and even security provision is also within responsibilities of this group in society. In other words, to realize a single criminal policy at a macro level requires not only participation by a wide variety of actors in this area, but also some sort of coordination and coherence among all elements abovementioned. Therefore, participatory criminal policy means that such a policy along with civil society participation, within framework of which other arms and organs work with police and judicial apparatus, allows for organizing responses to criminal phenomenon. Such cooperation and participation ensure that proposal developed by legislative and executive forces in the area of criminal policy, namely to engage general public in combating criminal phenomenon, is accredited (NajafiAbrandabadi, 2002: 265).

In this way, it can be argued that potentially governmental criminal policy is moving toward a participatory one representing public presence in and involvement with different phases of detection, arbitrator prosecution, execution of verdicts, and also prevention of delinquency. Put differently, governments cannot ignore effective roles people and NGOs play in various forms of controlling crimes. 


\section{Comparative Study of NGOs Participation in Criminal Processes}

People can participate in all different steps of criminal policy, but such participation and its quality vary from one country to another depending on dominant model of the policy in each country.

Today, International Criminal Court (ICC) is a pronounced example of NGOs' participation in criminal proceedings at both domestic and international levels. Information such organizations submit to ICC can be effective in preparing and filing criminal cases so that historical examination of ICC suggests a close relationship between ICC formation and NGOs which can help the Prosecutor obtain supplementary information. Under clause 2 of Article 15 of ICC statute, the prosecutor evaluates importance of obtained data when he initiates investigations personally based on obtained information. During this step, Prosecutor can ask NGOs to assist and help (Beigzadeh, 2013: 602).

Of course, rates of NGOs growth are not the same everywhere, for example, there are more than 16000 NGOs registered in Egypt while their establishment is forbidden in Saudi Arabia (Elbayar, 2005: 3).

Primary aspect of public participation in criminal processes relates to the issues of crime exposure and to its required prosecution and investigation, which remained active through contribution and participation of social groups to and in all criminal proceeding systems by disclosing and indicting crimes even after criminal networks were closed due to the appearance of government monopolizing it. Beyond that in some countries like England, ordinary persons are given powers to initiate prosecution and accusation, on the basis of which everyone (even if he is not a victim) can plead a general claim, following it through his counsel or lawyer like a private proceeding and trial until it ends. This was the case for French Law prior to 1789 Revolution. However, most prosecutions are initiated by police innovatives and acts, with people playing no significant roles in this field (Quoted from Delmas, Rostami, 2007; 142).

Even when criminal networks are closed to society due to the government appearance and monopoly, social groups, namely the society, associate with such a criminal network, primarily via members, and do tasks of disclosure and indiction of crimes, and production of witnesses, especially by participating in proceedings (as jury members in criminal courts and, recently, as public judges besides juvenile court judges). It should be noted that, compared to French legal system, in Common Law countries, layman judges are more and more present in proceedings (Delmas, 2014: 174). In viewpoint of comparative studies, in France, due to 2000 reforms and under Article 41 of criminal procedure code, in case one of crimes, for which NGOs are allowed to provide contribution and participation, is committed, public prosecutor informs these organizations of crime commission in order for victims to enjoy their help and assistance (Beziz - Ayache, 2003: 16).

To this practice of engaging social groups - whether individually or collectively - in criminal proceeding network or system have been added more active forms that illustrate actual participation of social groups NGOs - because, from now on, organized social groups enter this process in the form of grass root associations with continuous participation so that they will be considered a part of criminal system. In this way, participatory criminal policy is constructed by the re-distribution of roles between the government and civil society, aiming at advancing method of responsibility training and provision of local democracy grounds (Delmas, 2014: 174).

For public participation in crime exposure, of importance is the right to arrest provided for under Article 73 of French criminal procedure code, by virtue of which if an observable crime is committed, any other persons, in addition to victims, can arrest the perpetrator, direct him to the nearest police station and surrender him to judicial officers (Stephanie et al., 1998: 277).

Also, the U.S. Abuse Mandatory Reporting Act covers physicians and health care centers, educational jobs, legal jobs, law enforcement officers, outreach services and general public (Ghannad, 1998: 52). In this direction, social prosecution authorities in such countries as the U.S. deal with detection and exposure of crimes and related matters in relation to prosecution while being in contact with local officials (The Annie E. Casey Foundation, 2003: 25).

In the last few decades, participatory criminal policy strategies have been put on the agendas of UN and EU major legal institutions. Among steps taken are to prevent delinquency, to enhance cooperation in combating delinquency and specifically to combat against certain forms of delinquency by taking advantage of the intervening institutions ' participating internationally. In addition to formal criminal justice institutions in other countries, NGOs have assumed prominent roles in criminal processes from prevention, intervention to execution of sentences due to limited resources and facilities at disposal of formal criminal justice institutions and due to necessity of NGOs' interventions in order to support those anticipated matters being outside of jurisdiction of criminal justice system. 


\section{NGOs' Position in Domestic Laws and Regulations}

Constitutional Principle 26 provides that "freedom is awarded to known parties; populations; political, guild and Islamic associations: and minorities on the condition that they do not violate independence, liberty and national unity principles, Islamic standards and Islamic Republic base." Principle 27 also underlines freedoms of association and demonstration without carrying weapons conditional to not disrupting Islamic bases. To interpret mentioned principles, two views need paying attention to.

Based on constitutional assertion and dialect, populations and associations (including NGOs) are free to do their activities conditional to particular requirements.

After NGOs have been established, the government starts to monitor their compliance with said principles and fulfillment of established requirements prospectively, with constitution not emphasizing on retrospective monitoring. Therefore, NGOs are not required to obtain establishment and operation permit, with government monitoring them merely to see whether they violate requirements stated by Principles 26 and 27 or not. Although Constitution places no emphasis on retrospective monitoring, condition of observing said principles requires NGOs' and associations' qualifications to be ascertained, so it is necessary for them to obtain permit prior to their establishment. For legal personality of NGOs, it needs to be said that since they are considered non-governmental, they will enjoy title of a legal person on date of being registered with reference to Articles 584-586 of Trade haw. However, Registration of Companies Act provides for no mechanism for monitoring NGOs' operations; and to cancel their permissions depends on judiciary decisions by law rather than on court registry's.

In 1999, High Administrative Council identified respective apparatus as the Authority issuing permits and monitoring operation of NGOs, but High Administrative Court annulled that enactment. Another statute was formulated, since then being amended several times, identifying Home Department as authority issuing permits in order to regulate and organize such formations. Application for permits goes through some phases as follows: Review commission, also known as Article 2 commission, is formed at divisional, provincial and national levels in order to consider applications and issue permits, if appropriate. This commission secretariat is formed at three abovementioned levels within govern ship office, premier office, and Home Department. Permits are issued by National Article 2 Commission for operations of supraprovincial, national and international organizations. Each of Article 2 commissions create a regulatory committee to evaluate and monitor organizations being in the realm of their mission for their good faith in the statute enforcement, performance and to carry out preliminary investigations.

\section{Ways of NGOs' Participation in Criminal Processes}

Prior to 15/06/2015 amendment, Article 66, approved on 25/02/2014, stated "those NGOs whose statutes relate to the protection of children and teens, women, mentally or physically disabled persons, environment, natural resources, cultural heritage, public health and citizenship rights are authorized to indict crimes committed in relation to abovementioned domains, to produce evidence and to object to judgments". Having been amended, this Article provided, "those NGOs whose statute relates to providing protection of children and teens, women, mentally or physically disabled persons, environment, natural resources, cultural heritage, public health and citizenship rights are authorized to indict crimes committed in relation to abovementioned domains and participate in all proceeding steps".

\subsection{Right to Indict}

After the text of the Article had been amended, rights to produce evidence and to object to judgments were omitted; and, today, NGOs are entitled merely to indict crimes committed within the realm of their own activities, but not to sue legally.

Although many people may be damaged detrimentally by commission of a crime, merely direct victim, namely the person damaged by that crime and protected by legislator criminalizing a lawful conduct and/or being considered as deputy of such a person - is allowed to apply for the accused prosecution, at position of plaintiff, but indirect victims are not allowed to do so. Such a person is considered as an indictor of a crime and is eligible to do so (Khaleghi, 2014: 29). This aspect reflects private prestige regarding doing injustice to a given person's rights.

Under definition by Article 8 of new criminal procedure code, alternatively, a crime can be of the aspect of general prestige due to violating Divine limits and rules and/ or encroaching on social rights while breaching the public peace. Obviously, such certain crimes as those against environment, cultural heritage, natural resources and/ or public health are of general aspects in accordance with National Penal laws and since the society is the 
main beneficiary, any persons, including natural and legal, can indict.

By conferring right to indict, Article 66 has not given new powers to NGOs actually. Assuming that Act was not approved, non-governmental legal persons (NGOs) would be able to indict according to legal principles and articles, and this issue would be adopted through judicial precedent because, in Law, persons including natural and legal ones and their rights and responsibilities are basically spoken of.

\subsection{Right to Participate in All Proceeding Steps}

To believe in administration of justice is one of fundamental characteristics of legal systems. Constitutional Principle 165 provides, "Trials are held in public and individuals are permitted to attend unless the court recognizes it is filthy or disrupts public order, and/or, for private issues, unless conflict parties request for holding trials in camera".

Under Article 66, NGOs are permitted to attend proceedings. In this regard, its provision 4 recognizes that implementation of Article 66 is possible depending on Constitutional Principle 165 and provides that NGOs subject to this Article can only indict filthy crimes in case they observe Article 102 of criminal procedure code and its provisions and produce evidence to the courts, but they are not entitled to attend proceedings. Interesting point is that right to produce evidence in relation to filthy crimes has been given to NGOs in return for lapsing one right and conferring another. Therefore, it can be said that Article 66, in fact, has not given any new right or privilege to NGOs by asserting their right to participate in proceedings.

\section{Conditions for NGOs' Indicting and Participating in Proceedings}

Article 66 of criminal procedure code establishes conditions for NGOs' participating in proceedings as follows:

\subsection{Realm of NGOs' Activity}

In statute of NGOs' establishment, with structure of trustee board or general member assembly ${ }^{1}$, some terms and rules are determined and approved. Article 2 of which is for types of NGOs' activity ${ }^{2}$,Therefore, activities of NGOs intervening criminal processes should be not only subject to Article 66 of criminal procedure code, but also non-political and governmental non-profit.

As detailed in Article 66, domains of NGOs' activity are limitative, including those with statutes regarding provision protecting children and teens, women, mentally or physically disabled individuals, environment, natural resources, cultural heritage, public health and citizenship rights, and excluding other NGOs being active in areas of, for example, protecting prisoners, victims of occupational incidents, poor victims, etc. This results in dissatisfactions and objections from those NGOs that their activity realms are outside those provided for by the article.

\subsection{Meeting Conditions Established in Provision 3 of Article 66}

Provision 3 of Article 66 of criminal procedure code states that, "NGOs that can take steps to implement this article are nominated by Justice Minister with cooperation from Home Minister during first quarter of each year, and approved by Head of the Judiciary." Due to this limitation, legislator both has deprived judicial authorities of the right to determine NGOs' activities in respective domains and limited the nomination of NGOs to a list being prepared by Executive and Judiciary officials (Khaleghi, 2014: 72).

Regardless of the norm set forth in provision 3 of Article 66, some critics believe that if the statute of NGOs needs approving by the government, they will lose their autonomy.

Others believe that if the statute of an organization relates to one of items stated in Article 66 and if that organization establishment is accepted by Commission on Article 10 of Parties Act or is registered as a non-commercial, non-profit or charity organization without being listed under Provision 3, such an organization cannot be prohibited or deprived of the rights of indiction and attend proceedings as described by Article 66 since, having been recognized as a legal person by law, an organization cannot be prevented from doing activities for which it came into existence only by virtue of existence of procedural law.

It is possible that an NGO is not put on the list made by Home Department although it is not required to obtain permit under Constitutional Principle 26, even if it has obtained establishment permit from Home Department and even if it has gained status of a legal and judicial entity; and in case it is on the list proposed by Home

\footnotetext{
${ }^{1}$. See for more information, "Introduction of NGOs' principles, laws and regulations", Center of Home Department Social \& Cultural Affairs (Assistance of NGOs’ Affairs), 2011, (Saman.moi.ir).

2. Article 2) All Activities are of non-political and governmental non-profit types and ... these organizations will operate while observing all laws and regulations of Islamic Republic of Iran and of this statute.
} 
Department, its name and entity may not be approved by Judiciary Force, so it would be denied this very right to indict crimes (Azimi, 2015: 2).

Seemingly, the meaning of Provision 3 of Article 66 is not to select from NGOs arbitrarily, but rather under this provision, those organizations that are approved by Home and Justice Department are permitted to be active with respect to the Article. Such approval means having legal permit to do activities, having no criminal charges or record before the courts, and being qualified for mentioned organizations, based on implementary regulations, approved on 26/10/2015, of NGOs' establishment and operation.

The sole legal document for NGOs' operation is the permit issued by Home Department. Under Article 2 of the regulations, an NGO will gain legal personality after it obtains operation permit and is registered in accordance with standards set forth by regulations and with other current regulations. But being registered is not the necessary and sufficient condition of NGOs' entering the courts in order to indict and/or to sue against some person or institution, but rather it is essential for them to have no criminal and judicial charges or history, implying selection is based on qualifications.

\subsection{Obtaining the victims Consent: A Condition on NGOs' Intervention}

Since a plaintiff's will and desire are necessary to bring a criminal action regarding minor offences and since some individuals are always protected specifically by legislator due to their disabilities, Provision 1 of Article 66 states, "in case a crime is committed and there exists a given victim, his consent is required in order to take action. If the victim is a child, an insane or a silly person regarding financial offences, it is necessary to obtain his parent's, guardian's and/or legal custodian's consent, and in case the latter themselves have committed crimes, respective authority takes necessary steps by obtaining consent from an accidental guardian or by approval of general prosecutor.

\section{Barriers to NGOs' Intervention in Criminal Processes}

NGOs subject to Article 66 of criminal procedure code face significant barriers on the way of participating in criminal processes, including:

\subsection{Lack of Legal, Cultural and Social Contexts Necessary for Them to Participate in Criminal Processes}

NGOs can play their roles and gain their social positions when the state provides legal contexts and when cultural and social grounds develop. Grounds necessary to enforce laws related to NGOs have theoretically remained unchanged, with no roles foreseen for them to play in criminal processes prior to approval of the new criminal procedure code. In our country, there is no considerable interaction between formation of non-governmental organizations and process of regime operations. To create cultural and social grounds is one of requirements of expansion of these civil institutions.

\subsection{Lack of an Approved Comprehensive, Complete Act Governing and Monitoring NGOs and Their Activities}

Given that NGOs' participation in criminal processes is new and that they are now playing prominent roles in mentioned processes, it is necessary to monitor their operations and activities continuously and effectively in order to treat them proportionally and necessarily in case they violate general and professional rules in the course of following public claims. What are terms and principles complied with when NGOs' permits are to be extended and/or cancelled? If NGOs breach regulations, following items are punishments to impose on them, as determined by Article 2 commission:

a) Oral notification, with a 1-month moratorium for correcting the situation and preparing minutes of meetings.

b) Written notification, included in the case and with a 1-month moratorium for correcting the situation.

c) Suspension of activity permits.

d) Annulment of activity permits.

\subsection{Lack of Specified Norms and Criteria to Evaluate NGOs' Qualification in Terms of Intervening in Criminal Processes}

Although the Article text states that intended right would be given absolutely and unconditionally to all organizations whose statutes anticipated protection of disabled or weak groups, or of public and citizenship rights, the last provision has paved the way of the selection of NOGs arbitrarily and possibly discriminatorily. To evaluate individual organizations to determine whether they are qualified, they have internal conflicts, and they violate any of respective regulations is too time-consuming for Home and Justice ministers who introduce them to respectful Head of the Judiciary; This process takes more time than the first quarter of year. 


\subsection{Lack of a Foreseen Union or Assembly Coordinating and Monitoring Intra-Group Activities of NGOs}

It is not conceivable to think that all NGOs active in the same area can independently deal with one matter playing roles in the same proceedings, therefore, the need for an assembly or union is felt completely sensibly. It is discriminatory to select from NGOs arbitrarily, that is, one NGO cannot be considered as representing other relevant ones; so it is better for them to create a union or an assembly in order to exercise their rights so that they prevent possible discriminations and gain a strong support for their organizations and predetermined objectives.

\subsection{Limited Domains of NGOs' Activity Set Forth in Article 66 of Criminal Procedure Code}

As described in Article 66, domains of NGOs' activity are limited, excluding others which are active in protecting prisoners, victims of occupational accidents, poor victims, etc. This results in dissatisfactions and objections by excluded NGOs just mentioned.

\subsection{NGOs' Intervention is Limited to the Induction and Participation in Proceedings}

Prior to final amendment of criminal procedure code, NGOs enjoyed the rights to indict, nominate a representative to attend public prosecutor's office and the court as well as to obtain summons, give opinions and produce evidence before the court, and to object to the ruling given, on which to impose limitations minimizes NGOs' motivation to intervene in criminal processes because said Article has been enacted to provide support which cannot be materialized merely by indiction and participation although in-public proceedings are postulated with no prohibition being imposed in relation to people's presence.

\section{Discussion}

To expand NGOs' participation in criminal processes requires provision of activity grounds, activity monitoring and activity assessment in order to remove obstacles and drawbacks caused by their interventions. Although the tacts provided for by new criminal procedure code are regarded as an important step toward attracting public participation in criminal processes, especially in prosecutions regarding public claims, a long way is ahead to develop and establish a comprehensive system in relation to NGOs' participation; and it takes time to remove executive problems and obstacles. In this sense, the most important step to be taken is to amend laws governing NGOs' activities and to resolve ambiguities and barriers to interventions of NGOs in criminal processes. To enforce this law virtually brings proposed solutions about. Based on issues abovementioned, to foresee NGOs' participation in criminal processes as active followers, not indictors, will be a new, positive step to exposure and investigate crimes committed against persons needing others' help, on one hand, and crimes ruining public rights, on the other. In this way, NGOs, that have been trying to achieve their goals diligently for many years, can be provided with support seriously.

\section{References}

Azimi, M. (2015). Purpose Gem or Gloodsheding Wave? (Analysis of Article 66 of Criminal Procedure Code). Law School Monthly, (95).

Beigzadeh, A. (2013). Criminal Science (Collection of New Criminal Science Articles) (2nd ed.). Tehran, Mizan Legal Foundation Press.

Elbayar, K. (2005, September). NGO Laws in Selected Arab States Intimation. Journal of Not for-Profit Law, $7(4)$.

Ghannad, F. (1998). Criminal Protection of Minors against sexual offences on England \& Wales Legal System, M.A. Dessertation of Penal Law \& Criminology, Law School of Tehran Beheshti University.

Golmohammadi, S., \& Uosefi, A. (2009). NGOs' Roles and Participation in Development of Environmental Law. Quarterly of Mountain Environment, (14).

Hosseini, S. (2004). Criminal Policy in Islam and Islamic Republic of Iran (1st ed.). Tehran, Tehran University Press.

Jamshidi, A. (2011). Participatory Criminal Policy (1st ed.). Tehran, Mizan Press.

Khaleghi, A. (2014). Points of criminal procedure code (1st ed.). Tehran, Shahr-e Danesh Publication.

Khanjani et al. (2011). Introduction of Principles, Laws and Regulations of Non-governmental Organizations (1st ed.). Tehran: Assistance of NGOs Affairs, Home Department Social \& Cultural Center.

Lazorge, K. (2003). Introduction to Criminal Policy, Translation by Ali Hossein NajafiAbrandabadi (1st ed.). Tehran, Mizan Press.

Marty, M. (2002). Big Systems of Criminal Policy, Translation by Abrandabadi (Vol. 1). Tehran, Mizan Press. 
Mortazavi, S. (2009). Illegal Drugs \& Psychotropics Trafficking (Iranian \& French Criminal Policies with Reference to International Instruments) (1st ed.). Majd Publication.

NajafiAbrandabadi, A. H. (1993). Criminal Policy. Journal of Law Research, (11-12).

NajafiAbrandabadi, A. H. (1998). Delinquency, Insecurity Feeling, and Control. Justice Law Journal, (72).

NajafiAbrandabadi, A. H. (2012). Topics in Criminal Science (Criminology Textbooks) (7th ed.).

NajafiAbrandabadi, A. H., \& Hashembeigi, H. (2011). Criminology Encyclopedia (2nd ed.). Tehran, Ganj-e Danesh Library.

Nouri Neshat, S. (2006). Right-Centeric in Development. Tehran, Barg-e Zeitoon Publication.

Rahmdel, M. (2007). Iranian Criminal policy for drug-based crimes (1st ed.). Tehran, Samt Publication.

Rostami, V. (2007). Public participation in Criminal Processes, (Evaluation of Western Nations`Criminal Policy). Law Quarterly, Journal of Law and Political Science School, (2).

Sadeghi. (2010). Regionally Shared Criminal Policy: A factor effective in preventing crimes and drugs. Edalat Monthly, (86).

\section{Copyrights}

Copyright for this article is retained by the author(s), with first publication rights granted to the journal.

This is an open-access article distributed under the terms and conditions of the Creative Commons Attribution license (http://creativecommons.org/licenses/by/4.0/). 